\section{AUTOR:}

Alberto Mantovani Abeche

ORIENTADOR:

Prof. Dr. Eduardo Pandolfi Passos

Co-Orientador

Prof. Dr. Paulo Silva Belmonte de Abreu

\title{
Avaliação da percepção de qualidade de vida em puérperas adolescentes
}

\author{
Perceived quality of life of postpartum teenagers
}

\section{Resumo de tese}

Palavras-chave

Gravidez na adolescência

Qualidade de vida

Puerpério

Keywords

Adolescent pregnancy Quality of life

Puerperium
Tese apresentada ao Programa de Pós-graduação em Medicina: Ciências Médicas - Faculdade de Medicina da Universidade Federal do Rio Grande do Sul-UFRGS, para obtenção do título de Doutor, em 18 de fevereiro de 2009.

OBJETIVO: comparar a percepção da qualidade de vida em puérperas adolescentes e adultas, em seus diferentes domínios e dimensões, e investigar fatores que possam influenciar estes escores. MÉTODO: foi realizado um estudo transversal, prospectivo, avaliando 120 puérperas adolescentes e 120 puérperas adultas internadas no Hospital de Clínicas de Porto Alegre. Dados sócio-demográficos coletados incluíram: idade, escolaridade, estado marital (se mora com o companheiro ou não), planejamento e aceitação da gravidez. Dois instrumentos de avaliação da percepção de qualidade de vida, WHOQOL-bref e SF-36, foram aplicados a estas pacientes. A média dos escores destes instrumentos foi comparada entre puérperas adolescentes e puérperas adultas, bem como avaliados, entre os dados sócio-demográficos, aqueles capazes de influenciar a percepção da qualidade de vida das pacientes. RESULTADOS: com relação ao instrumento WHOQOLbref, verificou-se que as puérperas adolescentes apresentaram escore médio superior no domínio físico. Os escores dos demais domínios não diferiram significativamente entre os dois grupos. Avaliadas pelo instrumento SF-36, as puérperas adolescentes apresentaram escores médios superiores nos componentes da escala: capacidade funcional, limitação física e dor. Os demais componentes não diferiram significativamente entre os dois grupos. Em ambos os instrumentos, houve influência positiva sobre diversos domínios e dimensões quando houve reação positiva da adolescente e seu companheiro, ou quando a gravidez havia sido planejada. A idade média foi de 17,5 anos para as adolescentes e 24,8 anos para as adultas. CONCLUSÕES: a percepção de qualidade de vida em puérperas adolescentes não se mostrou inferior à das adultas, inclusive apresentando escores superiores em alguns componentes físicos e funcionais. Estes achados nos permitem compreender melhor as percepções e sentimentos das adolescentes em relação à maternidade. 